\title{
Toward a Genealogy of Modernism: Herder, Nietzsche, History
}

\author{
Peter Zusi
}

\begin{abstract}
He who merely inhales the scent of my plant does not know it, and he who plucks it merely in order to learn from it does not know it either. - Friedrich Hölderlin, Hyperion

The origin of all present-day architecture in iron and glass is the greenhouse.-A. G. Meyer, Eisenbauten
\end{abstract}

n 1874 the young Friedrich Nietzsche wrote: "To be sure, we need history; but our need for it is different from that of the pampered idler in the garden of knowledge." 1 Nietzsche articulates semantic associations that reverberate widely in twentieth-century modernism. His linkage of the modern historical sense with a stultifying, self-indulgent, indeed vegetable torpidity is evident, for example, in F. T. Marinetti's condemnation of the "smelly gangrene of professors, archaeologists, ciceroni and antiquarians" and rings especially clearly in Le Corbusier's exhortation that modern architects should "challenge the past" by rejecting the canons of historical eclecticism as "hot-houses where blue hortensias and green chrysanthemums are forced, and where unclean orchids are cultivated." Overturning long-established associations of

${ }^{1}$ Friedrich Nietzsche, "On the Utility and Liability of History for Life," in Unfashionable Observations, trans. Richard T. Gray (Stanford, CA: Stanford University Press, 1995), 85; Nietzsche, "Vom Nutzen und Nachtheil der Historie für das Leben," in pt. 2 of Unzeitgemäße Betrachtungen, vol. 1 of Kritische Studienausgabe, ed. Giorgio Colli and Mazzino Montinari (Munich: DTV; Berlin: de Gruyter, 1988), 245. Hereafter cited as "Utility" and "Nutzen," respectively.

I would like to thank Marshall Brown, Richard Gray, Maureen McLane, Françoise Meltzer, and Robert Pippin for reading and providing valuable criticism of this essay. 
the garden with pastoral or idealized states, Nietzsche's image stands at the inception of a powerful rhetorical tradition for expressing the modernist hostility to the past as such. ${ }^{2}$

For Nietzsche, the garden of historical knowledge is the site of two sins. The first is decadence. The spoiled idler, intoxicated by the heavy atmosphere of lush vegetation, is like a "curious tourist" casually examining the fruits of past accomplishment. By contrast, the true student of history, seeking places "where he finds inspiration to emulate and to improve ... does not wish to encounter the idler who, longing for diversion or excitement, saunters about as though among the painted treasures in a gallery" ("Utility," 96; "Nutzen," 258). The rootless idler views garden and gallery merely as forums for decadent self-indulgence rather than inspiration for new action: "Much harm stems from the thoughtless transplanting of these plants: the critic without affliction, the antiquarian without piety, the connoisseur of greatness unable to create something great are just such plants that, alienated from the natural soil that nurtures them, have degenerated and shot up as weeds" $(102 ; 264-65) .{ }^{3}$ The second sin is science. Nietzsche views the scientist's diligence as the pendant to the decadent's idleness: "curious tourists or meticulous micrologists" $\left(96 ; 25^{8}\right)$ are equivalent sources of annoyance to those seeking instruction in history. The decadent and the scientist

${ }^{2}$ F. T. Marinetti, "The Founding and Manifesto of Futurism," in Let's Murder the Moonshine: Selected Writings, ed. R. W. Flint, trans. R. W. Flint and Arthur A. Coppotelli (Los Angeles: Sun and Moon, 1991), 5o; Le Corbusier, Towards a New Architecture, trans. Frederick Etchells (New York: Dover, 1986), 7, 16. For a comparative analysis of the pastoral associations of the garden image in mid-nineteenth-century European literature see Gail Finney, The Counterfeit Idyll: The Garden Ideal and Social Reality in Nineteenth-Century Fiction (Tübingen: Niemeyer, 1984). Nietzsche's image of history as "negative pastoral" in certain respects anticipates avant-garde machine aesthetics and the frequent association of the present with technologized environments. Central discursive forms of modernist hostility to the past are surveyed in Jeffrey Schnapp, Michael Schank, and Matthew Tiews, "Archaeology, Modernism, Modernity," introduction to "Archaeologies of the Modern," special issue, Modernism/Modernity 11, no. 1 (2004): 3 (where the Marinetti quotation also appears).

${ }^{3}$ Here Nietzsche anticipates such commentators on the phenomenon of decadence as Joris-Karl Huysmans and Max Nordau. But he also picks up on a trend evident at least since Goethe's Elective Affinities, where the "naturalness" of the English garden - generally understood in the eighteenth century as the antidote to the decadent overcultivation of French and Dutch gardens - starts to assume sinister connotations of lawlessness or unleashed subterranean forces (see Finney, 66-69). 
share the intemperate desire to amass material and the inability to put it to use: the scientist's botanical samples, like the decadent's picture gallery, represent mere curiosity cabinets in which history becomes a dead object of observation rather than a live source of energy. ${ }^{4}$ The decadent sniffs plants, the scientist plucks them; neither profits from their life.

This garden was once different. Where Nietzsche finds rank weeds and poisonous blossoms, others found order and meaning. The metaphor of history as a garden full of unique and fragile blossoms was common in historical writing, especially that of the Historical School, against which Nietzsche's polemic was implicitly pointed. ${ }^{5}$ Yet the origins of the metaphor extend back farther. It was Johann Gottfried Herder who originally claimed that "the Earth might have been considered as a garden, where in one spot one human national plant, and in another, another, bloomed in its proper figure and nature." ${ }^{6}$ Herder,

4 "Has the constellation of life and history really been altered because a powerfully hostile star has come between them? . . . The constellation has, indeed, been altered-by science, by the demand that history be a science" ("Utility," 108-9; "Nutzen," 271).

${ }^{5}$ On the Historical School and its most famous protagonist, Leopold von Ranke, see Leonard Krieger, Time's Reasons: Philosophies of History Old and New (Chicago: University of Chicago Press, 1989), 97-106. Nietzsche neither directly mentions the Historical School nor uses the term historicism in "Utility." Nonetheless, Karl Heussi has described this essay as the work "in which one most of all senses it [the term historicism]" (Die Krisis des Historismus [Tübingen: Mohr, 1932], 2). Georg Gottfried Gervinus's $185^{2}$ preface to his history of the nineteenth century provides a fine example of this vegetable metaphor for history: "The little extraneous matter which is annexed ... is of unconstrained growth, deduced from the historical events themselves, and is free of all technicality of system, and from all the artifice of sophistry. The plant of reality, which appears here in the simple type of a law of nature, will, I trust, be found healthy and sound; and in the full blossom of the buds of promise which here and there appear, we also hope there may be discovered no trace of premature development [Treibkunst]" (Introduction to the History of the Nineteenth Century [London: Bohn, 1853], 12; Einleitung in die Geschichte des neunzehnten Jahrhunderts, ed. Hans Körnchen [Berlin: Dom, 1921], 9). On Wilhelm von Humboldt's use of the plant analogy to express the organic coherence he felt characteristic of historical knowledge see Georg G. Iggers, The German Conception of History: The National Tradition of Historical Thought from Herder to the Present, rev. ed. (Middletown, CT: Wesleyan University Press, 1983), 57.

${ }^{6}$ Johann Gottfried Herder, Outlines of a Philosophy of the History of Man, trans. T. Churchill (New York: Bergman, 1966), 349; Herder, Ideen zur Philosophie der Geschichte der Menschheit, in Herders Sämmtliche Werke, ed. Bernhard Suphan, 33 vols. (Berlin: Weidmann, 1877-1913), 14:84. Hereafter cited as Ideas and $S W$, respectively. The 
however, adopted the metaphor of a garden of history to illustrate his distance from the strict rationalism of Enlightenment science. In contrast to writers whose work he deemed "mechanical" historiography, such as David Hume, Voltaire, and William Robertson, Herder wished to portray history as a field of knowledge resistant to the categorical precision and nomothetic universalism of scientific thought. The garden metaphor expressed not only this contrast to mechanical rationality but also the urgency and relevance that Herder attributed to history as a source of knowledge of the present. The accounts of the Enlightenment historians, he maintained, were heavy with the dust of libraries, and thus he wished to send the historian out into the fresh air to move freely, perceive, and engage with the surrounding world. Somewhere in the century between Herder's and Nietzsche's visits, then, this garden became dreadfully overgrown. The fresh air turned into a greenhouse atmosphere.

More is at stake here than the fate of a metaphor: the transformation of the garden reveals a shift in the aspirations and hesitations associated with history as such. For Herder and Nietzsche, two of the most significant figures of the German Counter-Enlightenment, share the wish to demonstrate the hazards of an absolute faith in reason. ${ }^{7}$

garden of history is only one in a constellation of floral and vegetable metaphors in Herder's writings; many of these metaphors have complicated histories extending back to antiquity. See Edgar B. Schick, Metaphorical Organicism in Herder's Early Works: A Study of the Relation of Herder's Literary Idiom to His World-View (The Hague: Mouton, 1971); Marcel Janssens, "Das Bild der Pflanze und der Organismusgedanke im Schrifttum des jungen Herder," Jahrbuch des Wiener Goethe-Vereins, n.s., 67 (1963): 30-39; and August Langen, "Der Wortschatz des 18. Jahrhunderts," in Deutsche Wortgeschichte, ed. Friedrich Maurer and Heinz Rupp, 3rd ed., vol. 2 (Berlin: de Gruyter, 1974), 210-12. M. H. Abrams provides a classic account of the eighteenth-century context of some of this imagery, as well as of the broader trend of conceptual organicism to which it belonged, in The Mirror and the Lamp: Romantic Theory and the Critical Tradition (London: Oxford University Press, 1971), esp. chaps. 6-7.

${ }^{7}$ In this spirit D. Williams has portrayed Herder and Nietzsche as representing, respectively, the beginning and the end of an "essential Romanticism" that he deems characteristic of the German tradition ("Herder and Nietzsche," in Affinities: Essays in German and English Literature, ed. R. W. Last [London: Wolff, 1971], 256). Other commentators have noted remarkable parallels between aspects of Herder's and Nietzsche's thought. On metaphorical thinking see Wolfert von Rahden, "Nie wirklich satt und froh . . .' Nietzsches Herder," in Der frühe und der späte Herder: Kontinuität und/oder Korrektur, ed. Sabine Groß and Gerhard Sauder (Heidelberg: 
Their standpoint, however, is not antirationalist; rather, they turn the critical principles of Enlightenment rationalism against the Enlightenment itself. ${ }^{8}$ Thus both Herder and Nietzsche criticize what they perceive as an arrogantly self-confident and undialectical understanding of reason: one that engulfs the world but cannot turn back on itself and that creates a universe in its image by imagining itself to be universal. Herder and Nietzsche both criticize what can be called the "formalism" of Enlightenment rationalism, which filters the world through abstract categories that replace the vital exercise of creative cognitive energy generated from individual examples. Herder's and Nietzsche's critiques are at times strikingly similar. Yet Nietzsche hardly mentions Herder; indeed, as the transformation of the garden indicates, their accounts are deeply at odds. ${ }^{9}$ For Herder found the fundamental antidote to for-

Synchron, forthcoming); on theories of language see Tilman Borsche, "Natur-Sprache: Herder-Humboldt-Nietzsche," in Centauren-Geburten: Wissenschaft, Kunst und Philosophie beim jungen Nietzsche, ed. Tilman Borsche, Federico Gerratana, and Aldo Venturelli (Berlin: de Gruyter, 1994), 112-30; on Herderian echoes and influences in Nietzsche's psychology see Graham Parkes, Composing the Soul: Reaches of Nietzsche's Psychology (Chicago: University of Chicago Press, 1994), esp. 95-96, 257-58, 316 ; on the Dionysian in Herder and other precursors see Max L. Baeumer, "Nietzsche and the Tradition of the Dionysian," in Studies in Nietzsche and the Classical Tradition, ed. James C. O'Flaherty, Timothy F. Sellner, and Robert M. Helm (Chapel Hill: University of North Carolina Press, 1976), 166; and on Herder's philosophy of history as a precursor to Nietzsche's critique of metaphysics see Enno Rudolph, "Kultur als höhere Natur: Herder als Kritiker der Geschichtsphilosophie Kants," in Nationen und Kulturen: Zum 25o. GeburtstagJohann Gottfried Herders, ed. Regine Otto (Würzburg: Königshausen und Neumann, 1996), 13.

${ }^{8}$ In regard to Herder see Robert E. Norton, Herder's Aesthetics and the European Enlightenment (Ithaca, NY: Cornell University Press, 1991); and Regine Otto and John H. Zammito, eds., Vom Selbstdenken: Aufklärung und Aufklärungskritik in Herders "Ideen zur Philosophie der Geschichte der Menschheit" (Heidelberg: Synchron, 2001). Indeed, Herbert Schnädelbach argues that historicism in general "brought enlightenment to bear on the Enlightenment and in its critique of the Enlightenment was not simply a counter-Enlightenment" (Philosophy in Germany, I83I-1933, trans. Eric Matthews [Cambridge: Cambridge University Press, 1984], 37). In regard to Nietzsche see Robert B. Pippin, Modernism as a Philosophical Problem: On the Dissatisfactions of European High Culture, 2nd ed. (Malden, MA: Blackwell, 1999), 8o; and Stanley Rosen, The Mask of Enlightenment: Nietzsche's "Zarathustra," 2nd ed. (New Haven, CT: Yale University Press, 2004), 7. Parkes specifically compares Herder and Nietzsche in this respect (356).

${ }^{9}$ How directly Herder may have influenced Nietzsche is a difficult question. Michael N. Forster argues that "Nietzsche is strongly influenced by Herder" (introduction to Johann Gottfried Herder, Philosophical Writings, ed. and trans. Michael 
malist rationality in the historical understanding. Since history consists of unique and individual events, it resists the application of abstract categories. The lessons in logic that are gleaned from the study of history are not ends in themselves but help dissolve the rigid formalist habits obstructing the further cognitive development of humanity. A century later, however, Nietzsche's associations were quite the opposite: historical consciousness is the very soil from which a tangled formalism grows, and the garden of history represents mere raw material for the classificatory systems of a decadent botany. Nietzsche seeks the vital energy necessary to overcome modern scientific formalism not by turning to history but by appealing to "life" and to the ceaseless re-creation of identity. The deterioration of the garden thus expresses the following shift: for Nietzsche, resistance against formalist reason no longer sends one's glance backward to history, as for Herder, but forward to the next incorporation of life and to a present always just emerging from the future. For Herder, history mends decadent habits of thought; for Nietzsche, it is itself a decadent growth.

This shift represents a crucial move toward the condemnation of "masochistic reverence of historical values" and toward the outright denigration of history that is foundational for so much of twentieth-century modernism. ${ }^{10}$ Yet the parallels with Herder suggest that Nietzsche's critique of historicism does not so much overturn the rhetorical strategies and logic of early historicism as evolve from them. Those historicist hothouses vilified by Le Corbusier can stand as icons of this relation: for the cast-iron construction of nineteenth-century greenhouses in fact constituted an early exercise in the functionalism central to modernism itself. Analogously, Herder's historicist critique of formalism laid conceptual foundations for much of Nietzsche's modernist critique of historicism. A central component of modernist tem-

N. Forster [Cambridge: Cambridge University Press, 2002], vii). But there is little or no explicit evidence for this claim; indeed, Nietzsche's most substantial comment on Herder (in aphorism 118 of The Wanderer and His Shadow) is distinctly negative. Nonetheless, as Parkes (403), Rudolph (14), and von Rahden speculate, Nietzsche's condescension may indicate a bad conscience in regard to Herder's influence.

${ }^{10}$ Georg Grosz and John Heartfield, "Der Kunstlump," in Dada Berlin: Texte, Manifeste, Aktionen, ed. Hanne Bergius and Karl Riha (Stuttgart: Reclam, 1977), 86. 
porality - hostility to the past as such — thus traces its genealogy to the historicism it despised.

\section{Herder: The Cultivation of Reason}

Herder's critique of Enlightenment rationality in no way prevents him from sharing many standard Enlightenment positions. In Ideas towards a Philosophy of the History of Humanity, his mature work on the philosophy of history, Herder describes how a unified human nature links all societies despite the appearance of radical difference: "Notwithstanding the varieties of the human form, there is but one and the same species of man throughout the whole of our earth" (Ideas, 162; SW, 13:252).11 Herder hoped to contribute to a sense of human solidarity and tolerance and consequently to curb the violence and injustice caused by people's sense of difference from each other. ${ }^{12}$ He was convinced of the power of intellect to clear away superstition: "How many ancient fables of human monsters and deformities have already disappeared

${ }^{11}$ Herder's theory of climate illustrates this point well. Often interpreted as emphasizing the differentiating effects of climate and geography on societies, Herder in fact lays more emphasis on what remains constant throughout such variation: "No one will expect, for instance, that a rose should become a lily, the dog a wolf, in a foreign climate" (Ideas, $184 ; S W, 13: 284$ ). On how this emphasis sets him apart from the major French theorists of climatic influence (Montesquieu) see Gonthier-Louis Fink, "Von Winckelmann bis Herder: Die deutsche Klimatheorie in europäischer Perspektive," in Johann Gottfried Herder, I744-I803, ed. Gerhard Sauder (Hamburg: Meiner, $1987), 173$.

12 Thus Herder contrasts the differences resulting from climatic or cultural variation with the common features that distinguish all human beings from their closest relatives, the apes: "But thou, O man, honour thyself: neither the pongo nor the gibbon is thy brother: but the american $[\mathrm{sic}]$ and the negro [ $\mathrm{sic}]$ are: these therefore thou shouldst not oppress, or murder, or steal; for they are men, like thee; with the ape thou canst not enter into fraternity" (Ideas, 166; SW, 13:257; translations here and elsewhere occasionally modified slightly). On how Herder's concept of human unity informs his opposition to slavery see Dagmar Barnouw, "Political Correctness in the 1780s: Kant, Herder, Forster, and the Knowledge of Diversity," in HerderJahrbuch/Herder Yearbook, I994, ed. Wilfried Malsch and Wulf Koepke (Stuttgart: Metzler, 1994), 54-56. For Herder's influence on critics of British colonial policy in the 184 os see John Boening, "Herder and the White Man's Burden: The Ideen zur Philosophie der Geschichte der Menschheit and the Shaping of British Colonial Policy," in Johann Gottfried Herder: Language, History, and the Enlightenment, ed. Wulf Koepke (Columbia, SC: Camden House, 1990), 236-45. 
before the light of history! and where tradition still repeats remnants of these, I am fully convinced that the stronger light of inquiry will clarify [aufklären] them into more beautiful truths" (165; 13:255). Increasing knowledge and tolerance will triumph over prejudice and superstition: clearly, a mainstream Enlightenment thought. Nevertheless, the above passage indicates where Herder himself departs from that mainstream. While "light" and "enlightenment" are still the victors over fable and superstition, the mechanism of enlightenment has changed: where one would expect to find the "light of reason," one finds the "light of history" instead. ${ }^{13}$

The valorization of history reflects another side of Herder's project: his critique of "mechanical" reason. In particular, the groundbreaking earlier text This Too a Philosophy of History for the Formation of Humanity laments how the systematic knowledge so prized by Enlightenment thinkers loses touch with real life:

On paper how pure!, how gentle!, how beautiful and great-but hopeless in execution!, at each step amazed and staring frozen before unseen obstacles and consequences. ... One rationalizes! Dictionaries and philosophies about all of them, without understanding a single one of them with the tool in one's hand. They have one and all become abrégé raisonné of their former pedantry-abstracted spirit!, philosophy out of two thoughts - the most mechanical thing in the world. ${ }^{14}$

Surprisingly, Herder associates "mechanical" reason not with functionality but with passive observation. Systematic knowledge is acquired

13 To be sure, as the further phrase "light of inquiry" indicates, the displacement of reason by history in this passage is not absolute: Herder does not claim that the turn to history requires the abandonment of the claims of rational inquiry. Nonetheless, he is possibly using the term "inquiry" (Untersuchung) in the Herodotian sense

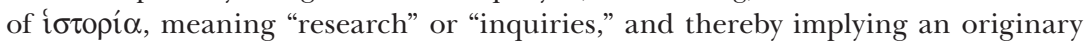

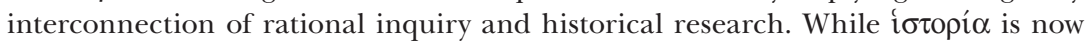
generally translated as Forschung, older dictionaries rendered it as Untersuchung as well; see, e.g., Friedrich Wilhelm Riemer, Kleines griechisch-deutsches Hand-Wörterbuch, pt. 1, 2nd ed. (Jena: Fromann, 1815), 678-79.

${ }^{14}$ Johann Gottfried Herder, This Too a Philosophy of History for the Formation of Humanity (1774) (hereafter cited as TTP), in Philosophical Writings, 317-18; SW, $5: 536-37$. Here and in the following citations, the abundant emphases are Herder's. Even in this early text, which in reasoning and rhetoric stands much more in the eye of the Sturm und Drang than does the later Ideas, one finds a similar linkage of enlightenment and historical investigation; see, e.g., TTP, 272; SW, 5:477. 
only by refusing to roll up one's sleeves and engage with the messiness of everyday reality. Purity produces paralysis.

Herder, of course, could not ignore the global power that Enlightenment rationality had helped bring to Europe. But, paradoxically, he equated European geopolitical might with a loss of cultural vitality:

In Europe the grown harvest of the ancient world-centuries was due only to be dried and pressed-but to come from there among the peoples of the earth. . . . Everything was already invented, felt, subtly thought up that perhaps could be thought up; here everything now got cast into method, into scientific form. And now, next, there came in addition precisely the new, coldest mechanical inventions which writ everything large: machines of cold northern European abstraction, great tools for the hand of Him who guides everything! — now the seeds lie there almost among all nations of the earth. . . Europe dried, strung, eternalized them. (TTP, 339; SW, $5: 563-64)$

While Europe's world-historical role as codifier of ancient wisdom enabled an enormous geographic expansion of the cultural inheritance of antiquity, it presupposed simplification and desiccation: the "grown harvest" of the ancient world became transportable across the globe only because it was dried out and stripped of vitality. More ominously, European expansion barbarously exploited the rest of the world. ${ }^{15}$ European conquest and dominance, therefore, concealed passivity and moral decline.

Under the regime of Enlightenment, cultural values derived from felt experience likewise suffered. They shriveled into "method" and "scientific form." Mechanical reason demands that experience be repeatable; it passes over what is individual to embrace "the bright, splendid Universal" (TTP, 317; SW, 5:536). Enlightenment reason thereby gains an expansive power of self-propagation. But the logical capacity to sub-

15 “' 'Our system of trade!' Can one imagine anything superior to the subtlety of this all-embracing science? What miserable Spartans they were who used their Helots for agriculture, and what barbaric Romans who shut up their slaves in prisons in the earth! In Europe slavery has been abolished because it has been calculated how much more these slaves would cost and how much less they would bring in than free people. Only one thing have we still permitted ourselves: to use as slaves, to trade, to exile into silver mines and sugar mills, three parts of the world-but those are not Europeans, not Christians, and in return we receive silver and gemstones, spices, sugar, and-secret disease" (TTP, 328; SW, 5:550). 
sume unique cases under generalizing first principles constitutes a form of cognitive colonialism that could not be justified even by self-interest or cynicism. In its violence toward everything diverging from the ruling schemata, mechanical reason ultimately weakens those wielding its power. Systems of abstract or generalizing logic, unhindered by responsibility toward the ambiguity of reality, proliferate uncontrollably until the modern thinker is "deluged with beautiful first principles, developments, systems, expositions - deluged to the point that hardly anyone any longer sees the ground and has a footing" (321; 5:540-41). Too much undirected explanatory power is debilitating: "Think not, sons of men, that a premature, disproportionate refinement or cultivation is happiness; that the dead nomenclature of all the sciences . . . can secure to a living being the science of life. . . The more we divide our mental powers by refinement, the more the idle powers decay" (Ideas, 220; SW, 13:336). Universalizing reason is enervating: it creates power and luxury at the price of decadent spiritual torpor.

Against moral and physical idleness Herder advocates "life." After describing, for example, how the decline of Roman civilization was followed by the invigorating influx of barbarian tribes, Herder remarks:

Now, is it better, is it healthier and more beneficial for humanity, to produce mere lifeless cogs of a great, wooden, thoughtless machine, or to awaken and rouse forces? Even if it should be through so-called imperfect constitutions, disorder, barbaric stickling about honor, savage addiction to quarreling, and such things - if it achieves the purpose, then it is still definitely better than while alive being dead and moldering. (TTP, 301; SW, 5:516)

The Roman Empire subordinated diverse peoples and cultures to a uniform ruling structure. In contrast to the mechanizing image of "lifeless cogs," the unruly bustle of Germanic tribes, Slavs, and Huns is equated with vitality and impassioned uniqueness. The "savage ... quarreling" that other observers might find drearily uniform represents for Herder the jostling of secure individual identities. Similarly, in the later Ideas the notion of vital force motivates the more concordant central image of a garden of history nursing the diverse "national plants." Since each culture or society is unique, even the humblest flora express an irreplaceable life force. Conversely, even the most magnificent vegetation eventually withers and dies: "The plant blossoms and fades: your fathers have died, and mouldered into dust: your temple is fallen: your taber- 
nacle, the tables of your law, are no more: language itself, that bond of mankind, becomes antiquated: what? and shall a political constitution, shall a system of government or religion, that can be erected solely on these, endure forever?" (Ideas, 351; SW, 14:88). Judged by vitalist criteria, the proud Enlightenment claim to have brought human society to a point of perfection admitting no further development appears not only arrogant but also deeply misguided. Everything fades; there can be no exceptions. But transience carries no stigma, for it is not simply inevitable but also the sign of life. The Enlightenment ideals of perfection and permanence, by contrast — even if they could be achieved — would imply not strength but merely inorganic stasis.

History, as the arena in which vital force produces unique and constantly changing forms, thus provides conceptual lessons that refute formalist logic. It is futile to evaluate the past (as Herder felt that Enlightenment historians such as Hume, Voltaire, and Robertson tried to do) with "the one form of their time" (TTP, 296; SW, 5:508). Such a priori standards are alien to the phenomena and prevent unique forms from revealing themselves without distortion. Only a flexible and holistic approach does justice to historical complexity: "The whole nature of the soul, which rules through everything ... in order to share in feeling in this, do not answer on the basis of the word but go into the age, into the clime, the whole history, feel yourself into everything [fühle dich in alles hinein] — only now are you on the way towards understanding the word" (292; 5:503). In this vision of a truly historical, antiformalist mode of cognition, Herder coins two terms - empathy (Einfühlung) and understanding (Verstehen) - in a usage that practically sets the program for nineteenth-century historicism. ${ }^{16}$ Empathy describes an identification with another time or culture so intense that one leaves behind the assumptions, values, and standards of one's own time. It

16 On Herder as the "creator of a new method of 'empathy' (a word that he himself invented)" see Friedrich Meinecke, Historism: The Rise of a New Historical Outlook, trans. J. E. Anderson (London: Routledge and Kegan Paul, 1972), 297; Meinecke, Die Entstehung des Historismus (Munich: Oldenbourg, 1936), 385 . On the role of the term Verstehen in nineteenth-century historicist discourse see Hans Georg Gadamer, Truth and Method, 2nd rev. ed., translation revised by Joel Weinsheimer and Donald G. Marshall (New York: Continuum, 1994), esp. 179-218; Schnädelbach, 109-38; and Joachim Wach, Das Verstehen: Grundzüge einer Geschichte der hermeneutischen Theorie im I9. Jahrhundert, 3 vols. (Tübingen: Mohr, 1926-33). 
presupposes a temporary loss of independent subjectivity: a forgetting of oneself to achieve a fuller, less distorted understanding of an initially alien subject. Friedrich Meinecke describes the process: "Understanding of the other through empathy . . . would only be possible . . by breaking down the rigid division between subject and object, by realizing that everything is interconnected and works together, not only in a causal and mechanical sense, as the Enlightenment had also perceived, but by virtue of an inner community of being and oneness of the whole" (Historism, 315; Entstehung, 408). Empathy thus causes a momentary loss of self: passive but perceptive openness displaces the actively judging subject. Herder sees this as the only alternative to formalist reason and the only route to real understanding. The twin concepts of empathy and understanding, therefore, describe the logical mode he found appropriate to the antiformalist principles of historical reason.

\section{Nietzsche: In the Presence of History}

A century after Herder's work on the philosophy of history, Nietzsche's "On the Utility and Liability of History for Life" polemicized against an allegedly rampant cultural ill: the bloated consciousness, indeed fetishization, of the historical past. The historicism of the Historical School, the unnamed target of Nietzsche's attack, claimed Herder's philosophy of historical reason as a legacy. Nietzsche nonetheless perceived contemporary historicism not as an alternative to but as a degenerate form of scientific thought. Thus the reversal in the garden metaphor: historical consciousness represented not the cure for but the very source of decadent idleness and deadening formalism.

Nietzsche's text often reads like an antihistoricist, early modernist manifesto. ${ }^{17}$ "Life," the creative force that Nietzsche feels hyperbolic historicist consciousness withers, expresses an "incandescent point in time" (de Man, 147) that begins to cool into an ossifying formalism as soon as it slips into the past. Modernity and history thus relate to

${ }^{17}$ See esp. Paul de Man, "Literary History and Literary Modernity," in Blindness and Insight: Essays in the Rhetoric of Contemporary Criticism, 2nd ed. (Minneapolis: University of Minnesota Press, 1983), 142-65. De Man reads "Utility" in conjunction with Baudelaire's "Painter of Modern Life" as an archetypal expression of the radicality and paradoxes of modernist temporality. 
each other like fire and water: history is unequivocally destructive of the vital force driving the ceaseless self-creation of the modernist. ${ }^{18}$ Yet at other moments Nietzsche seems quite serious about the claim that "life requires the service of history" ("Utility," 96; "Nutzen," 258). Here the polemic targets not history as such but historicism: the degenerate consciousness of history distinctive of nineteenth-century Europe. ${ }^{19}$ Nietzsche therefore wavers between a Herderian notion of history as furnishing a vital antidote to formalist thought and a modernist or indeed avant-gardist notion of history as stifling the creative energy of the present moment. Ultimately, however, his rhetorical momentum registers a crucial ideological shift toward the vilification of history tout court. The judicious balance announced in the essay's title-history can be useful as well as harmful — hardly comes through in the body of the text. For historical consciousness to be vital, Nietzsche claims, it must make history present.

Still, Nietzsche's antihistoricist polemics invoke distinctly Herderian terms and logic. These echoes are immediately discernible, for example, in the crucial notion of life force. Nietzsche, like Herder, regards the direction or manner in which life force radiates as unimportant; indeed, Nietzsche claims that life force cannot be contained by moral considerations. Vitality generates injustice: "It takes great strength to be able to live and forget the extent to which living and being unjust are one and the same thing" (107; 269). Life, in other words, requires curbing mental and moral faculties: action is impossible without embracing simplifications about the world and accept-

18 As de Man puts it: "Modernity and history are diametrically opposed to each other in Nietzsche's text. Nor is there any doubt as to his commitment to modernity" (148).

19 Thus Volker Gerhardt claims that "the assessment of the second of the Unfashionable Observations as an 'anti-historical polemic,' which is in any event theoretically implausible, is also refuted in practice" ("Leben und Geschichte: Menschliches Handeln und historischer Sinn in Nietzsches zweiter 'Unzeitgemäßen Betrachtung," ' in Pathos und Distanz: Studien zur Philosophie Friedrich Nietzsches [Stuttgart: Reclam, 1988], 135; see also 141). Andreas Huyssen asserts that "texts such as . . . the second of the Untimely Meditations on the uses and abuses of history demonstrate that they fully understood the dialectic of innovative drive and museal desire, the tension between the need to forget and the desire to remember" (Twilight Memories: Marking Time in a Culture of Amnesia [New York: Routledge, 1995], 19). 
ing that the active expression of one's own identity presupposes the transgression of someone else's. Herder also hints that one must often subordinate moral considerations to the sheer vitality of affect:

"That it should be unintelligible to anyone in the world how light does not nourish human beings!, how tranquility and luxury and so-called freedom of thought can never be universal happiness and vocation!" But sensation, movement, action-even if subsequently without purpose (what on the stage of humanity has an eternal purpose?), even if with blows and revolutions, even if with sensations which here and there become fanatical, violent, even awful - as a tool in the hands of the course of time, what power!, what effect! Heart and not head nourished! Everything bonded with inclinations and drives, not with sickly thoughts! . . . Fermentation of human forces. A great cure of the whole species through violent movement, and if I may speak so boldly, fate wound up (certainly with a great din and without the weights being able to hang there peacefully) the great wound-down clock! So the wheels rattled there! (TTP, 3०9; $S W, 5: 5^{2} 5^{-26}$ )

Herder here superimposes Newtonian and Leibnizian mechanism onto the theological view that ongoing divine intervention determines human history; his clock is wound by human passions rather than by divine miracles. Only affect makes the motion of human history perpetual. Providence may direct history, but its designs remain unknown to the human agents contributing the blind energy driving the motion.

Thus Herder and Nietzsche both equate life force with undirected energy: expressiveness requires explosiveness. Yet, paradoxically, this is a constructive explosiveness; life force lacks teleology but does have productive consequence. For expression transforms difference into a unique, unitary, and recognizable shape, which Nietzsche calls the "shaping power of a human being, a people, a culture. . . I mean that power to develop its own singular character out of itself, to shape and assimilate what is past and alien, to heal wounds, to replace what has been lost, to recreate broken forms out of itself alone" ("Utility," 89; "Nutzen," 251). The ability to transform "into its own blood" (90; 251), to consume and incorporate outside data of perception, is the essence of creative expression. A culture infused with expressive vitality displays a unified "style": "The culture of a people that is the antithesis of that barbarism was once termed ... the unity of artistic style that manifests itself throughout all the vital self-expressions of a people" (111; 274). 
The voracious explosiveness of life force, therefore, secures unique identity. Eclectic origins are transformed as if by consuming fire: "what is past and alien" becomes fuel for the expression of signature forms of an original physiognomy. ${ }^{20}$

But Nietzsche also echoes Herder in the complementary notion of the experiential horizon. While life force cannot be directed by external considerations such as morality, it does require an internal protective space within which to be concentrated. This represents "a universal law: every living thing can become healthy, strong and fruitful only within a defined horizon" (9o; 251). Nietzsche opposes focused creative identity to the diffuse and derivative culture of "walking encyclopedias," while Herder opposes it to those who equate knowledge with "dictionaries" (110-11; 274; TTP, 318; SW, 5:537). Herder claims, for example, that the narrow perspective of a village lawmaker generates action where the sophisticated legal theorist remains mired in theoretical subtleties:

Between every universally stated, even the most beautiful, truth and its least application there is a gulf! And application in the single right place?, for the right purposes?, in the single best way? — The Solon of a village who has really eliminated only one bad habit, set in motion only one stream of human sensations and activities - he has done a thousand times more than all you rationalizers about legislation, with whom everything is true and everything false - a miserable universal shade. (TTP, 322; SW, 5:542)

Herder's wise village lawmaker solves problems because of his intimacy with and internalization of the needs and customs of a particular community. Wisdom, in other words, flows from focus on the particular,

${ }^{20}$ Here Nietzsche clearly represents a source for what Peter Sloterdijk terms the literature of Weimar's "Epochen-Physiognomik," whose organicist logic and frequent lapses into atavism and "neo-mythical impulses" often brought it close to fascism ("Weltanschauungsessayistik und Zeitdiagnostik," in Literatur der Weimarer Republik, I9I8-1933, ed. Bernhard Weyergraf [Munich: DTV, 1995], 310). See also Richard T. Gray, About Face: German Physiognomic Thought from Lavater to Auschwitz (Detroit: Wayne State University Press, 2004). Herder is commonly identified as a crucial early source for this discourse, although the complexities of his (and Nietzsche's) organicism are far greater than is generally acknowledged; see, e.g., my " 'Kein abgefallenes Blatt ohne Wirkung geblieben': Organicism and Pluralism in Herder's Metaphorics of Culture," in Groß and Sauder. 
from application rather than abstraction. Consider Nietzsche's strikingly similar image:

A human being's historical knowledge and sensitivity can be very limited, his horizon as narrow as that of the inhabitant of an isolated alpine valley . . . yet in spite of all these injustices and all these misconceptions, he stands there, vigorously healthy and robust, a joy to look at. At the same time, someone standing close beside him who is far more just and learned grows sick and collapses because the lines of his horizon are restlessly redrawn again and again, because he cannot extricate himself from the much more fragile web of his justice and his truths and find his way back to crude wanting and desiring. ("Utility," 9o-91; "Nutzen," 252)

The narrow field of vision of these two rustic village dwellers brings a bold capacity to curb contemplation, consideration, and thus hesitation. Since hyperconsciousness causes paralysis of the will, a narrowed perspective does not confine but liberates. Reflection must be cut off somewhere - perhaps randomly, perhaps ruthlessly - if a conclusion is to be reached and acted on. ${ }^{21}$

The failure to draw a horizon results in excess or repletion, consumption without hunger. For Nietzsche, cognitive gluttony is the sin of the historically educated European, who cannot digest the vast quantities of historical information consumed. Instead of being transformed into self-expression, knowledge remains an eclectic mass of detail that weighs on the body and results in torpor: "Knowledge consumed in excess of hunger - indeed, even contrary to one's need-now no longer is effective as a shaping impulse directed outward" ("Utility," 109-10; "Nutzen," 272). Echoing Herder's (more polite) formulation that "a head stuffed with knowledge . . oppresses the body" (Ideas, 220; $S W, 13: 33^{6}$ ), Nietzsche offers the striking image of modern historians incapacitated by the greedy consumption of "indigestible stones of knowledge" (“Utility," 109; "Nutzen,” 272). Clearly, consuming inorganic objects brings little nourishment.

When gluttony destroys the experiential horizon and when "all perspectives have shifted," unity of artistic style fragments into the "unsur-

${ }^{21}$ Despite the sinister reverberations of these passages, the idea that a narrow but clear sense of national self-interest results in bold (and therefore admirable) action remains politically potent to the present day. 
veyable spectacle" of eclecticism (109; 272). Undigested, the stones of knowledge simply grind against each other. Nietzsche regards eclecticism as the curse of mid-nineteenth-century Europe: creative historical identity degenerates into passive imitation of past cultural forms.

But even this indictment arises in Herder, who asks: "If your head is full of a group that you have fallen madly in love with, can your view well embrace, order, gently follow, a whole of such changing periods . . . ? But if you can do none of that!, history shimmers and flickers before your eyes!, a confusion of scenes, peoples, periods" (TTP, 293; $S W$, $5: 504-5)$. His conclusion that "we, therefore, if we want to be Orientals, Greeks, Romans all at once, we are reliably nothing" (332; 5:554) anticipates Nietzsche almost literally: "We moderns have nothing that we have drawn from ourselves alone; we become something worthy of attention ... only by stuffing and overstuffing ourselves with alien times, customs, arts, philosophies, religions and knowledge" ("Utility," 110-11; "Nutzen," 273-74). For both, the shimmering spectacle of historical eclecticism masks the absence of cultural identity, and both associate the loss of creative individuality with parasitic formalism or, as Nietzsche describes it, the diremption of "single, vital unity" into "inner and outer, content and form" (111; 274).

The parallels between Herder and Nietzsche end abruptly when each posits his own mechanism for constructing the experiential horizon. Herder's mechanism is empathy: by immersing oneself in the past, by losing one's subjectivity in another subject, one escapes the infinite, paralyzing reflectivity of Enlightenment reason. But Nietzsche emphatically rejects empathy. He equates it with the Rankean dictum of Selbstauflösung (dissolution of the self) as a misguided measure of pure objectivity. Nietzsche sees objectivity, perhaps the most injurious consequence of applying scientific criteria to history, as "eternal subjectlessness," passivity or "impotentia" (120-21; 284-85). Forbidding all interest in or desire for an object, objectivity impedes action and selfexpression, in effect constituting a voluntary renunciation of identity. Nietzsche describes self-proclaimed objective historians in decidedly unflattering terms:

We are dealing with a race of eunuchs; and for a eunuch one woman is just like any other, just a woman, woman-in-herself, the eternally unapproachable - and hence it makes no difference what you do, as long as 
history itself remains neatly "objective" and is preserved by those who themselves can never make history. And since the Eternal Feminine will never draw you upward, you drag it down to your level, and since you are neuters, you consider history to be a neuter, as well. (120; 284)

Instead of bringing the phenomenal world closer (as empathy does for Herder), objectivity holds it at a distance: an object of passive perception, quelling passion and affect and thus the motivation to action.

Nietzsche rejects Herder's ideal of empathy, but he formulates his own, largely analogous principle. He regards the capacity to forget as the key to focusing life force. Memory accompanies the human psyche as a sort of doom: a chain obstructing forward movement, a ghost that "disturbs the peace of a later moment" $(87 ; 248)$. Forgetting liberates one from the reflexivity of consciousness, which otherwise continually returns to the past. Without such liberation, life force cannot be focused into action: "All action requires forgetting, just as the existence of all organic things requires not only light, but darkness as well" (89; 250). Nietzschean forgetting, like Herderian empathy, defends against mental distractions and thus traces the lines of the horizon, allowing vital concentration for action. Both represent an escape from the iron cage of infinite reflexivity (understood as the perpetual return either of the experienced moment or of our own conceptual presuppositions). For Herder, the historian sacrifices the present and makes contact with the past by forgetting the conceptual measures of his own epoch. For Nietzsche, the active subject sacrifices the past and makes contact with the present by forgetting the forms of previous epochs. Thus the contrast between the mechanisms of empathy and forgetting seems to constitute the dividing line between Herder's historicism and Nietzsche's early modernist antihistoricism.

Remarkably, even this clear contrast disguises underlying affinities. Nietzschean forgetting, despite its emphasis on absorption in the present moment, does not represent outright indifference to the past. Rather, Nietzsche insists on forgetting that one has used the past by consuming and transforming it into something new. "Critical history," the most important historical mode, involves ruthless revaluation of one's origins and rejection of the injustice inevitably found there. As such, critical history represents a "temporary suspension" of forgetfulness so as to bring previously unquestioned preconditions and habits 
"before a tribunal" (107, 106; 269). The critical faculty of judgment of the past then spurs action: rejection of or revolution against origins now deemed unjust; creation of new habits, institutions, and so on. Nietzsche describes this process as a whitewashing of the past: "This is an attempt to give ourselves a posteriori, as it were, a new past from which we would prefer to be descended, as opposed to the past from which we actually descended" (107; 270). This act of historical sanitation is the moment of vital creativity or identity construction that most interests Nietzsche. But to become complete, forgetting must return in the form of belief in the lie just constructed and denial of the origins now rejected. Nietzschean forgetting, therefore, does not describe a creation myth of absolute autochthony so much as a creative game of self-deception: the transformation of deficient origins into fictional originality.

Rejection of the past thus always presupposes a return to the past, and Nietzsche's vocabulary expresses this ambivalence. Tellingly, he recurs to the image of the decadent garden: the critical historical sense takes "a knife to its roots" to "cultivate" (pflanzen) new habits and create a "second nature" $(107 ; 270)$. Forgetting occurs once one regards the self-fashioned second nature as if it were first nature. One uproots only to transplant, and although Nietzsche originally criticized such transplanting as the source of degeneration and alienation, it apparently is preferable to complete rootlessness. Despite the rhetoric of rejection, Nietzsche has not left Herder's garden after all.

If Nietzsche's disregard for the past is more nuanced than it first seems, so is Herder's disregard for the present. Historical consciousness never implies for Herder indifference to contemporaneity. Ernst Behler points out that by critiquing dominant intellectual paradigms, Herder was obviously "engaged in the modernity debates of his time." 22 Further, Herder feels that historical consciousness presents tools for understanding not only past cultures but one's own historical positioning as well: "Consciousness of absolute historicity" leads to "consciousness of [one's] own modernity in contrast to the epoch coming to a close"

22 Ernst Behler, "Historismus und Modernitätsbewusstsein in Herders Schrift Auch eine Philosophie der Geschichte zur Bildung der Menschheit," in Etudes germaniques 49 (1994): 270 . 
(Behler, 269). ${ }^{23}$ But finally, more is at stake than simply registering innovations in intellectual habits, for Herder takes the radical position that it is impossible to be truly modern without abandoning the hermeneutic fallacy of standing outside history. Originality is impossible without genealogical knowledge: understanding modernity as unique is the dialectical product of understanding historical variation. In Reinhart Koselleck's words, "Diagnosis of the neue Zeit and analysis of the past eras corresponded to each other." 24 While too rarely acknowledged, this modernist impulse in Herder's historicism echoes resoundingly in the period that separates him from Nietzsche. Indeed, Herder's "historicist modernism" anticipates what James Chandler terms the "preoccupation with contemporaneity" of British Romantic historicism in the 1820 , echoes further in Baudelaire's recognition in 1863 that "every old master has had his own modernity," and (as I hope to have shown) remains clearly discernible even in Nietzsche's antihistoricist text of $1874 \cdot{ }^{25}$

To be sure, the ever-accelerating denigration of history is undeniable as modernism becomes more dominant during the later nineteenth century. On some fundamental level Nietzsche did express the reversal of the logical charge Herder had assigned to historical consciousness (even as he retained the general structure of Herder's critique of formalist rationality). For Nietzsche welds history to formalism to create "historicism": a major legacy to twentieth-century modernist discourse, associating desiccation, decadence, and weakness with the past as such. Nonetheless, the modernist rejection of history emerges far more smoothly than is generally admitted out of the early historicist tradition modernism so reviled. Tracing the genealogy of Nietzsche's critique of historicism back to Herder's historicist texts complicates the

${ }^{23}$ Behler claims, moreover, that "Herder sees the most characteristic feature of his modernity in the historical-philosophical consciousness" described in TTP $(274-75)$.

${ }^{24}$ Reinhart Koselleck, Futures Past: On the Semantics of Historical Time, trans. Keith Tribe (New York: Columbia University Press, 2004), 240.

${ }^{25}$ James Chandler, England in I8I9: The Politics of Literary Culture and the Case of Romantic Historicism (Chicago: University of Chicago Press, 1998), 106; Charles Baudelaire, "The Painter of Modern Life," in The Painter of Modern Life and Other Essays, ed. and trans. Jonathan Mayne (London: Phaidon, 1995), 12. 
modernist ideology of a rejection of the past and provides renewed appreciation of the modernist impulse underlying the late-eighteenthcentury historical turn.

Peter Zusi is lecturer in Slavic languages and literatures at Harvard University. His recent publications include "The Style of the Present: Karel Teige on Constructivism and Poetism," Representations, no. 88 (2004), and “'Wie ein Kind ist unser Volk': Hybrid Identity and National Consciousness in Rilke's Zwei Prager Geschichten," German Quarterly 79 (2006). 
- 